\title{
SOME PHYSICOCHEMICAL PROPERTIES OF ACID PROTEASE PRODUCED DURING GROWTH OF ASPERGILLUS NIGER (NRRL 1785)
}

\author{
F. M. OLAJUYIGBE, J. O. AJELE and T. L. OLAWOYE \\ (Received 15 May 2003; Revision accepted 11 July 2003)
}

\begin{abstract}
The growth of Aspergillus niger (NRRL 1785) was investigated and monitored over a five-day fermentation period. Acid protease synthesis by this fungus was also investigated during the period. The effect of growth of Aspergillus niger on acid protease synthesis was determined. Some of the physicochemical properties of the acid protease were examined. The growth curve obtained for Aspergillus niger revealed four phases of growth which are the lag phase, the exponential phase, the deceleration phase and the death phase. Acid protease synthesis by Aspergillus niger increased in direct proportion to growth up to the early hours of the death phase. Maximum enzyme synthesis was obtained at the 96 th hour of fermentation, which was 12 hours into the death phase. The acid protease synthesized had optimum $\mathrm{pH}$ of 4.0 , while the enzyme was stable ( $60 \%$ relative activity and above) over a wide range of $\mathrm{pH} 2.5-5.5$. The optimum temperature for acid protease was determined to be $50^{\circ} \mathrm{C}$. The enzyme was also stable up to this temperature $\left(50^{\circ} \mathrm{C}\right)$ at $\mathrm{pH} 4.0$ for 1 hour. Calcium ions had activating effect on the acid protease while sodium and mercury ions had inhibitory effects. The results obtained in this paper show a direct correlation between the growth of Aspergillus niger and acid protease synthesis, hence the particular phase of growth of Aspergillus niger determines the extent of enzyme yield by the fungus.
\end{abstract}

KEYWORDS: Proteolytic enzyme; Acid protease; microbes; Aspergillus niger

\section{INTRODUCTION}

Proteases are proteolytic enzymes devived from a wide range of sources and have widely differing $\mathrm{pH}$ and temperature optima and specificities (Kalisz, 1988). They are one of the most important groups of enzymes constituting two thirds of the total industrial enzymes marketed (Singh et al., 1994). Acid proteases have been isolated and characterized from mammals, plants, fungi, yeast, retrovirus and bacteria (Wu and Hang, 1998). Acid proteases play an important role in meat tenderisation and in the production of fermented foods by molds rom soybean, rice and other cereals (Nout and Rombouts, 1990; Gerhartz, 1990).

Microbial acid protease are usually preferred to enzymes from plant and animal sources due to the rapid growth rate of microorganisms, large quantity of enzymes produced, the ease of purification and the potential of microbes to be engineered towards acquiring novel characteristics. Many factors are known to affect the production of the enzyme in a culture brew. Specifically, it has been reported that the biosynthesis or production of the proteases is often correlated with a particular phase of the microbial culture (Hagspiel et al, 1989). It has been reported that enzymes from different strains of microbes belonging to the same species do differ in their biochemical characteristics (Mchahon et. al., 1999).

In this paper, the growth of Aspergillus niger (NRRL 1785) was studied and some physicochemical properties of the acid protease produced during the growth were determined.

\section{MATERIALS}

\section{Microorganism}

Aspergillus niger (NRRL 1785) isolated from stale milk and maintained on Potato Dextrose Agar was obtained from the Federal Institute of Industrial Research, Oshodi (FIIRO), Lagos, Nigeria.

\section{Chemicals}

Chemicals and Reagents were products of Sigma Chemical Company, St. Louis, USA and Merck, Darmstadt, Germany.

F. M. OLAJUYIGBE, Department of Eiochemistry, Federal University of Technology, Akure, Nigeria

J. O. AJELE, Department of Biochemistry, Federal University of Technology, Akure, Nigeria

T. L. OLAWOYE, Department of Biochemistry, Federal University of Technology, Akure, Nigeria 


\section{METHODS}

\section{Preparation of Fermentation Medium For Growth of Culture \\ Aspengillus niger (NRRL 1785)}

constituted the parent culture. The method used in preparing the fermentation medium followed that of Sarath et al (1989) with modifications. The culture conditions and media for growth and synthesis of acid protease by Aspergillus niger were optimized to give maximum growth and enzyme production. The optimized medium was referred to as a basal medium. The basal medium contained $2 \%$ glucose, $1 \%$ mycological peptone, $0.1 \% \mathrm{KH}_{2} \mathrm{PO}_{4}$ and $0.3 \%$ yeast extract. The $\mathrm{pH}$ of the medium was adjusted to 4.0 using $0.05 \mathrm{M}$ citrate buffer.

Spore inoculum of Aspergillus niger under study was prepared by adding $5 \mathrm{ml}$ sterile distilled water to a 5 day old slant culture of Aspergillus niger NRRL 1785 with vigorous shaking for 1 minute and poured aseptically into the basal medium. The resulting mixture was incubated at $30^{\circ} \mathrm{C}$ for 24 hours in a Gallenkamp Economy Incubator. Fermentation media in which the Aspergillus niger was grown and acid protease synthesis monitored were prepared in like manner with the basal medium to cover a 5day fermentation period. $5 \mathrm{mi}$ inoculum was pipetted from the mixture of basal medium and spores into each fermentation medium. These were later incubated at $30^{\circ} \mathrm{C}$ on a Gallenkamp Rotary Shaker at $200 \mathrm{rev} / \mathrm{min}$ for the period ranging from 12 to 120 hours.

\section{Determination of Growth of Aspergillus niger (NRRL 1785)}

Growth of Aspergillus niger (NRRL 1785) and acid protease synthesis were monitored at intervals of 12 hours. At the end of each fermentation period, the fermentation broth was filtered through pre-desiccated and pre-weighed filter paper. The residue, which was the mycelium, was dried in an airtight Gallenkamp oven at $105^{\circ} \mathrm{C}$ for 3 hours to obtain the dry weight of the mycelium. The dry weight of the mycelium was recorded as biomass concentration in $\mathrm{mg} / 100 \mathrm{ml}$ of broth and used to measure the growth of Aspergillus niger. The clear filtrate was the source of the acid protease.

\section{Assay of Acid Protease activity}

The synthesis of acid protease by Aspergillus niger under study was measured through the assay of acid protease activity in the fermentation broth. The assay procedure was that of Sarath et al (1989), which comprised setting up the test, blank and standard. The test contained reaction mixture of $\mathrm{Iml}$ of $1 \% \mathrm{w} / \mathrm{V}$ casein (substrate), $0.4 \mathrm{ml}$ of $0.05 \mathrm{M}$ citrate buffer, $\mathrm{pH} 4.0$ and $1.0 \mathrm{ml}$ enzyme solution. One millilitre (1.0mi) of buffer replaced enzyme solution in the blank while the standard was prepared with tyrosine $(100 \mathrm{\mu g} / \mathrm{ml})$. The test and the blank were incubated at $50^{\circ} \mathrm{C}$ for 15 minutes; the reaction was stopped by adding $3.0 \mathrm{ml}$ of $5 \%$ trichloroacetic acid to precipitate the enzyme. The mixtures were later centrifuged at $5000 \mathrm{rpm}$ for 15 minutes and the supermatant was collected. Four millilitre $(4.0 \mathrm{ml})$ of $0.4 \mathrm{M}$ sodium carbonate were added to $1.0 \mathrm{ml}$ of supernatant with thorough mixing. Five hundred microlitres $(0.5 \mathrm{ml})$ of Folin - Ciocalteau reagent were added to the mixture and this was left for 10 minutes to allow for colour development. The absorbance at $660 \mathrm{~nm}$ was determined in a Biochrom UV/Visible spectrophotometer (Pharmacia LKB). One unit of acid protease activity was defined as micrograms of tyrosine equivalents per minute under the standard assay conditions.

Some Physicochemical Properties of Acid Protease Synthesized by Aspergillus niger (NRRL 1785)

\section{Effect of $\mathrm{pH}$ on acid protease activity}

Citrate buffer $(0.05 \mathrm{M})$ of different $\mathrm{pH}(2.5$ -6.5) were prepared. The acid protease activity was determined at varying $\mathrm{pH}$. The citrate buffer of the $\mathrm{pH}$ under study replaced the citrate buffer of $\mathrm{pH} \mathrm{4.0}$ in the standard assay procedure above.

\section{Effect of $\mathrm{pH}$ on the stability of acid protease}

Enzyme solution $(1.0 \mathrm{ml})$ was incubated with buffer of test (or the $\mathrm{pH}$ under study) for 24 hours at room temperature, after which the $\mathrm{pH}$ of the enzyme solution was adjusted to 4.0 with $0.05 \mathrm{molL}^{-1}$ citrate buffer, $1 \mathrm{ml}$ of substrate solution ( $1 \%$ casein) was then added to the enzyme buffer solution and the acid protease activity was assayed at $50^{\circ} \mathrm{C}$ as earlier outlined. The activity obtained was termed residual activity.

\section{Effect of temperature on acid protease activity}

Water baths were set at temperatures ranging from $30^{\circ} \mathrm{C}-80^{\circ} \mathrm{C}$. The assay reaction mixture was incubated at the different temperatures for 15 minutes after which the acid protease activity was determined.

Effect of temperature on stability of acid protease

Enzyme solution (1.0ml) was incubated at different temperatures $\left(30^{\circ} \mathrm{C}-80^{\circ} \mathrm{C}\right)$ for one 


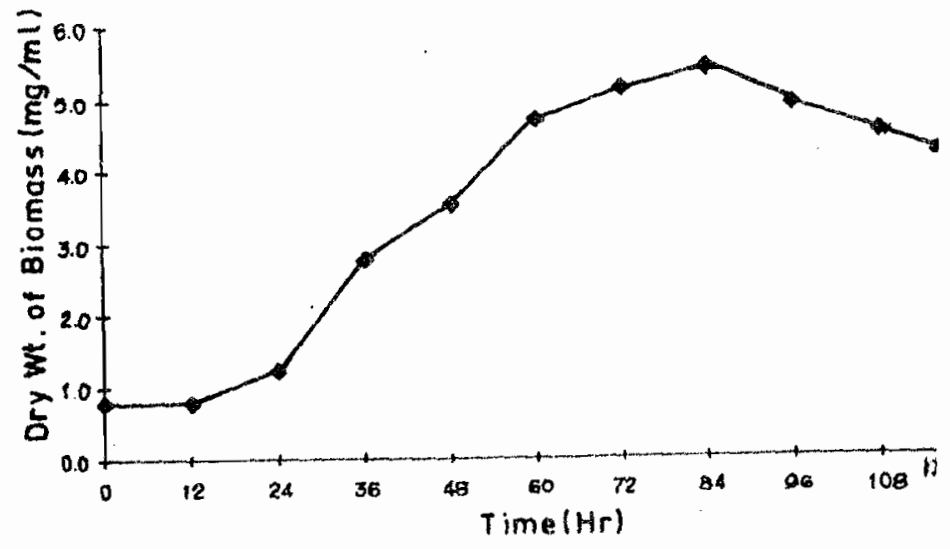

Figure 1: Fermentation Profile of Aspergillus niger NRRL 1785 showing the dry weight of Biomass (growth) against time.

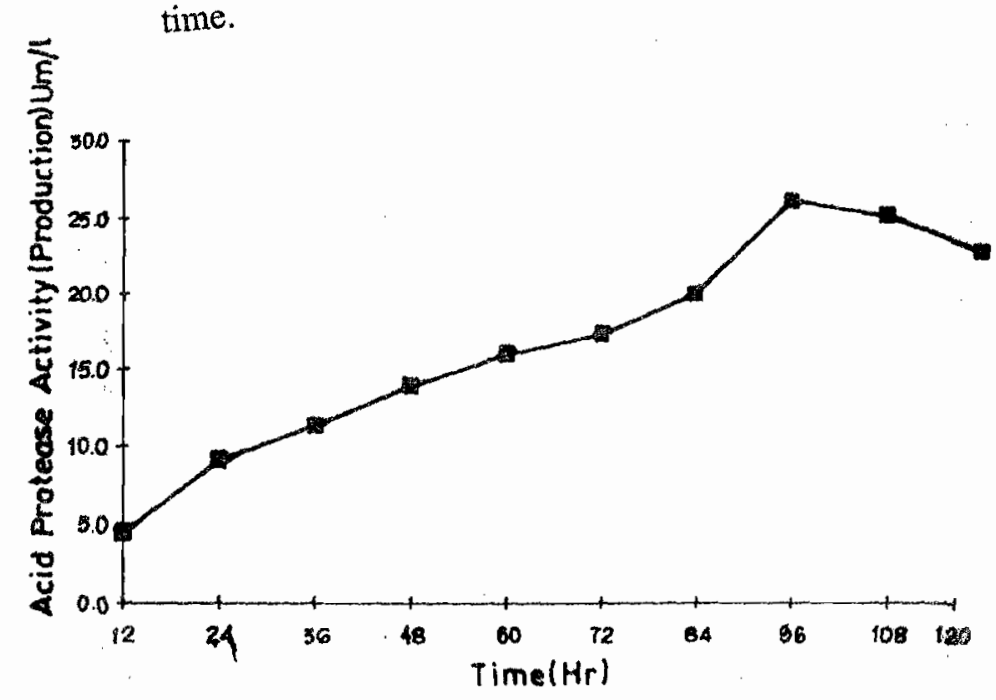

7igure 2: Fermentation Profile of Aspergillus niger NRRL 1785 showing the acid protease activity (protease production) against time

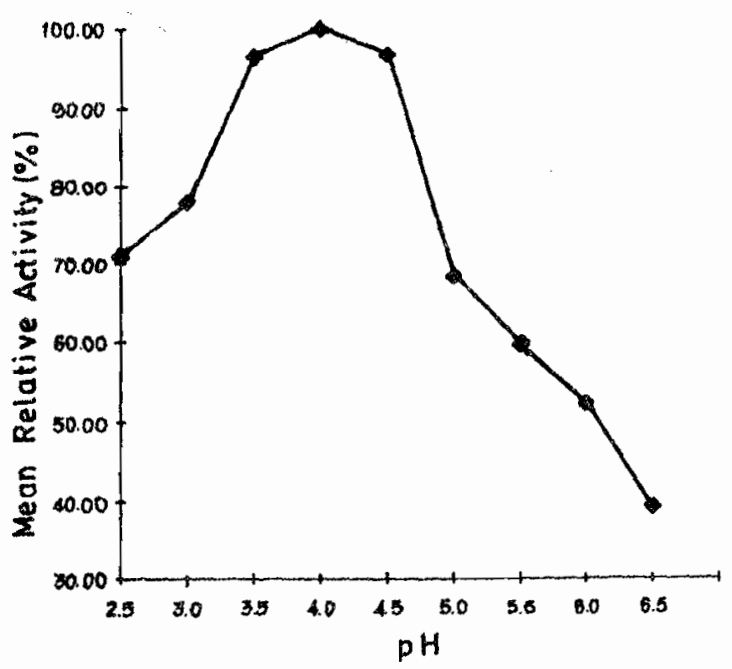

Figure 3: Effect of $\mathrm{pH}$ on acid protease activity hour after which the acid protease activity was determined following the assay procedure.

Effect of metar ions on acid protease activity Six different salts (Calcium chloride, Sodium chloride, Magnesium sulphate, Mercury chloride, Copper sulphate and Lead acetate) were tested for their effect on acid protease activity at a concentration of $50 \mathrm{mM}$. Enzyme solution (1.0ml) was incubated with $0.4 \mathrm{ml}$ of each salt solution at room temperature for 30 minutes after which the acid protease activity was assayed.

\section{RESULTS}

\section{Growth of Asperyilhus miger (NRRL 1785)}

The pattern of growth of Aspergillus niger is illustrated in Fig. 1 . It consists of four phases of growth: the lag phase (0-12 hrs), exponential phase (12hrs - 60hrs), deceleration phase (60hrs - 84hrs) and the death phase (84hrs - 120hrs).

\section{Symthesis of Acid Protease}

There was a lag period of about 12 hours before the commencement of synthesis (Fig. 2) after which enzyme activity began to appear in the medium. Synthesis of acid protease continued to increase until the $96^{\text {th }} \mathrm{hr}$ when a maxirnum activily of $26.05 \mathrm{Uml}^{-1}$ was obtained.

\section{Physicochemical Properties}

Effect of $p H$ on acid protease activity

The effect of $\mathrm{pH}$ on acid protease activity is shewn in Fig. 3. Acid protease activity increased with $\mathrm{pH}$ from $\mathrm{pH} 2.5$ to $\mathrm{pH} 4.0$ after which it began to decrease. The optimum pH was 4.0. Reslative activity was expressed as a percentage of the activity at pH 4.0 , which was taken as $100 \%$.

\section{Efrect of pH on acid protease stabiny}

The offest of pH on acid protease stability is shown in Fig. 4. The optimum pH for enzyme stability was pH 3.5. The residual activity was expressed relative to the activity at $\mathrm{pH}$ 3.5. The activity at the optimum pH was taken as $100 \%$. The enzyme was said to be stable at any $\mathrm{pH}$ at which relative residual acid protease activity was greater than $60 \%$. From the figure below, the enzyme was stable over the $\mathrm{pH}$ range of $2.5-5.5$.

\section{Effect of temperature on acid protease activity}

Acid protense activity increased with increase in temperature up to $50^{\circ} \mathrm{C}$, where the 


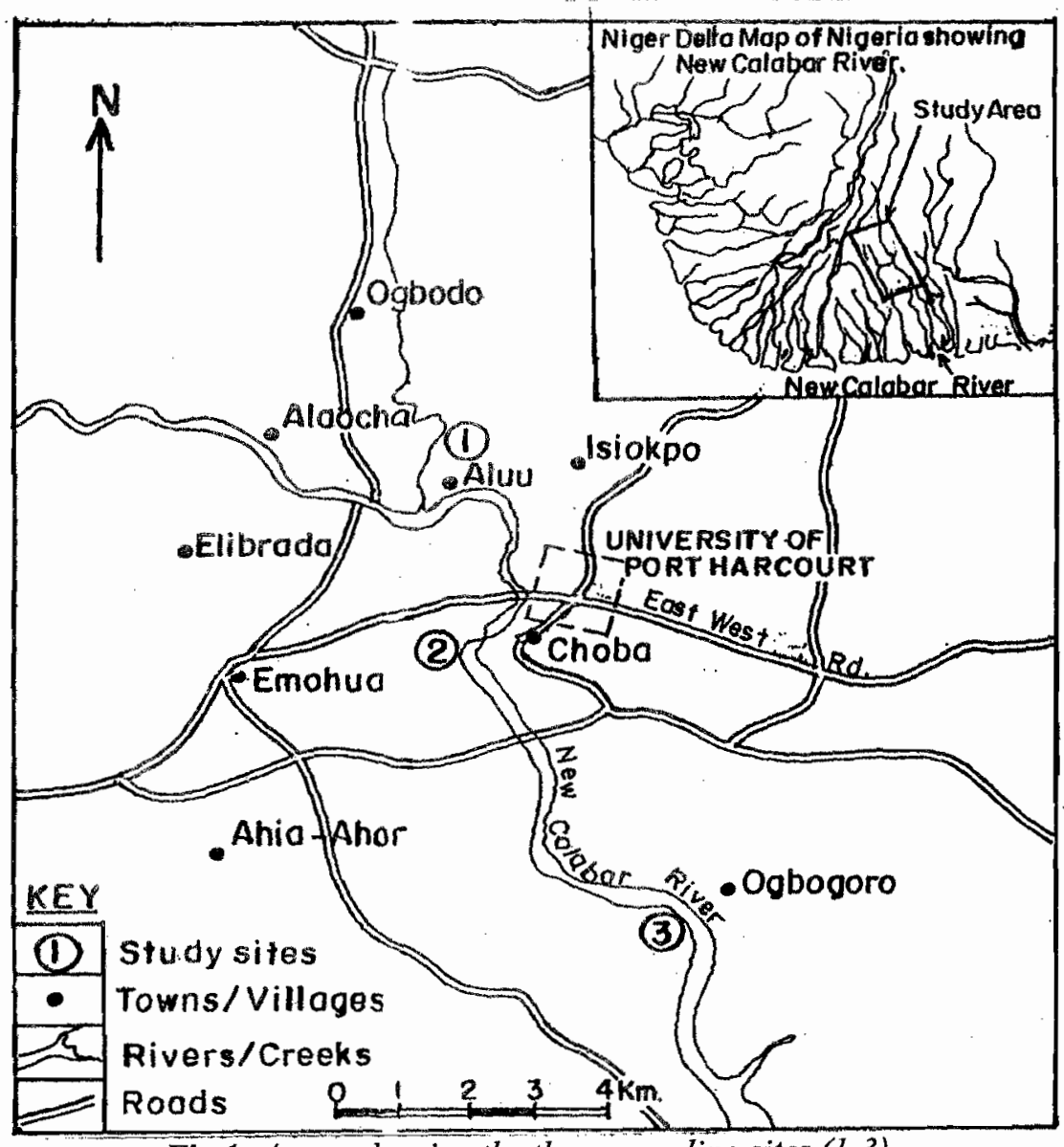

Fig 1: A map showing the three sampling sites (1-3) of the New Calabar River.

(Laddaga and Silver, 1985), biosynthesis of metallothineins and other proteins that trap metals (Higham et al., 1984), precipitation (Aiking et al., 1985), and transformation to volatile compounds (Meissner and Falkinham, 1984).

Although many different chemical methods have been employed to remove metals from wastewater, for example hydroxide and sulphide precipitation, ion exchange, membrane processes (Metzner, 1977) addition of natural and synthetic polymers and acid treatment (Wheatland et al., 1975). The technique of selective bioaccumulation of heavy metals by microbial systems offers the best possible approach for the remediation of contaminated water bodies.

This study was thus conducted to investigate seasonal changes in the distribution of heavy metal resistant bacteria and the probable contribution of inputs of heavy metals by industrial effluent discharges into the New Calabar River water and sediment.

\section{MATERIALS AND METHODS}

\section{STUDY AREA}

The New Calabar River is found in the lower Niger Delta, near Port Harcourt, Nigeria
(Figure 1), with its source at Elele Alimini Umeozoro. It is freshwater from source to Aluu and brackish beyond this point. The river water is soft and acidic with $\mathrm{pH}$ 5.5-6.5 (Odokuma and Okpokwasili 1993a; Odokuma and Okpokwasili 1993b; Odokuma and Okpokwasili, 1997).

\section{SAMPLE COLLECTION AND PRESERVATION}

Three sampling points were chosen for this study:-At-Choba. (site 2); an oil servicing company (WB), a fibre processing industry (HF) and a market are located. At Ogbogoro (site 3), a construction company (SPC), and a mini-market are present. Aluu (site 1) has no industrial activity.

Samples were collected using 2-itre sterile water containers. Containers were prewashed with detergents, then with distilled water, soaked with $95 \%$ alcohol and allowed to dry. At points of collection, containers were rinsed severally with the river water and then used to collect samples from the, surface $(0-15 \mathrm{~cm})$ and sub-surface $(15-30 \mathrm{~cm})$ of the river. Eckman grab sampler was used for collection of sediments samples.

A total of nine sampling trips were 


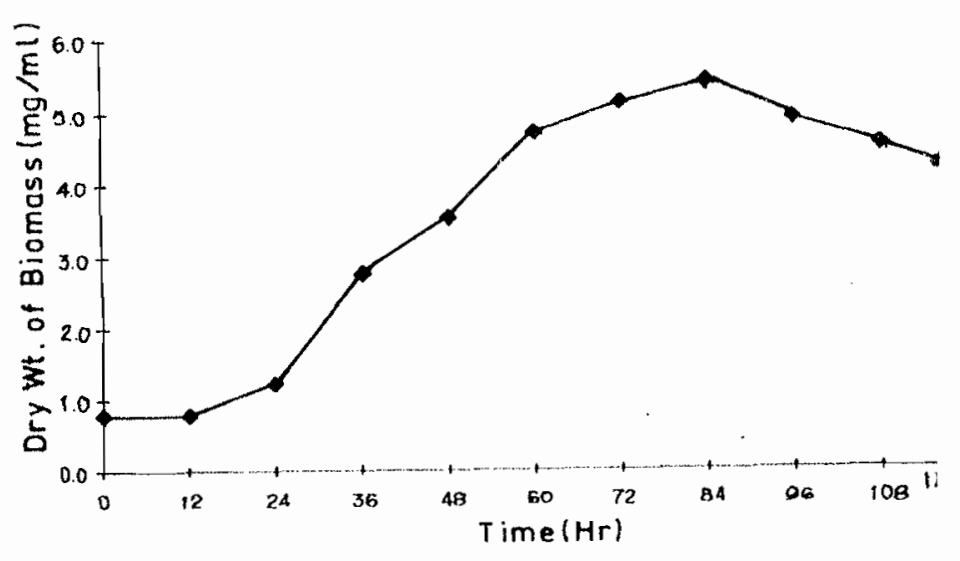

Figure 1: Fermentation Profile of Aspergillus niger NRRL 1785 showing the dry weight of Biomass (growth) against time.

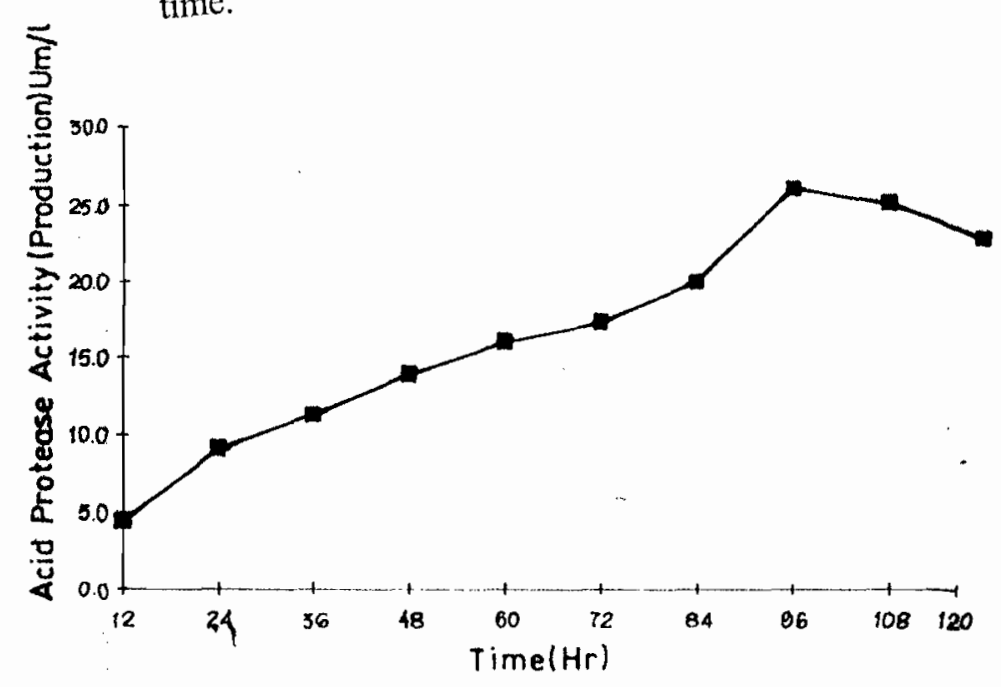

Figure 2: Fermentation Profile of Aspergillus niger NRRL 1785 showing the acid protease activity (protease production) against time

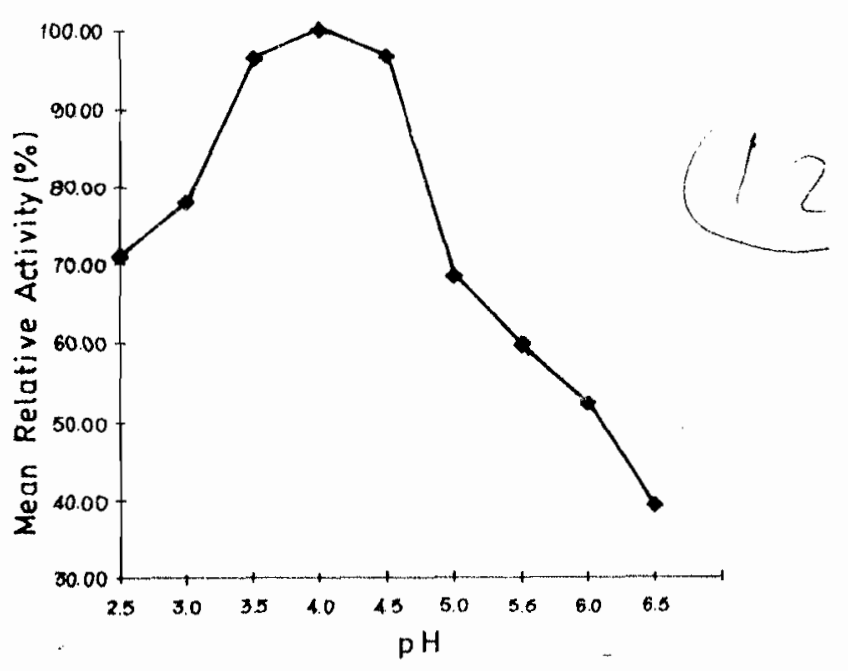

Figure 3: Effect of $\mathrm{pH}$ on acid protease activity hour after which the acid protease activity was determined following the assay procedure.

Effect of metal ions on acid protease activity Six different salts (Calcium chloride, Sodium chloride, Magnesium sulphate, Mercury chloride, Copper sulphate and Lead acetate) were tested for their effect on acid protease activity at a concentration of $50 \mathrm{mM}$. Enzyme solution $(1.0 \mathrm{ml})$ was incubated with $0.4 \mathrm{ml}$ of each salt solution at room temperature for 30 minutes after which the acid protease activity was assayed.

\section{RESULTS}

\section{Growth of Aspergillus niger (NRRL 1785)}

The pattern of growth of Aspergillus niger is illustrated in Fig. 1. It consists of four phases of growth: the lag phase $(0-12 \mathrm{hrs})$, exponential phase ( $12 \mathrm{hrs}-60 \mathrm{hrs}$ ), deceleration phase (60hrs - 84hrs) and the death phase (84hrs - 120hrs).

\section{Synthesis of Acid Protease}

There was a lag period of about 12 hours before the commencement of synthesis (Fig. 2) after which enzyme activity began to appear in the medium. Synthesis of acid protease continued to increase until the $96^{\text {th }} \mathrm{hr}$ when a maximum activity of $26.05 \mathrm{Jml}^{-1}$ was obtained.

\section{Physicochemical Properties \\ Effect of pH on acid protease activity}

The effect of $\mathrm{pH}$ on acid protease activity is shown in Fig. 3. Acid protease activity increased with $\mathrm{pH}$ from $\mathrm{pH} 2.5$ to $\mathrm{pH} 4.0$ after which it began to decrease. The optimum $\mathrm{pH}$ was 4.0. Relative activity was expressed as a percentage of the activity at $\mathrm{pH} 4.0$, which was taken as $100 \%$.

\section{Effect of $\mathrm{pH}$ on acid protease stability}

The effect of $\mathrm{pH}$ on acid protease stability is shown in Fig. 4. The optimum $\mathrm{pH}$ for enzyme stability was $\mathrm{pH} 3.5$. The residual activity was expressed relative to the activity at $\mathrm{pH}$ 3.5. The activity at the optimum $\mathrm{pH}$ was taken as $100 \%$. The enzyme was said to be stable at any $\mathrm{pH}$ at which relative residual acid protease activity was greater than $60 \%$. From the figure below, the enzyme was stable over the $\mathrm{pH}$ range of $2.5-5.5$.

\section{Effect of temperature on acid protease activity}

Acid protease activity increased with increase in temperature up to $50^{\circ} \mathrm{C}$, where the 


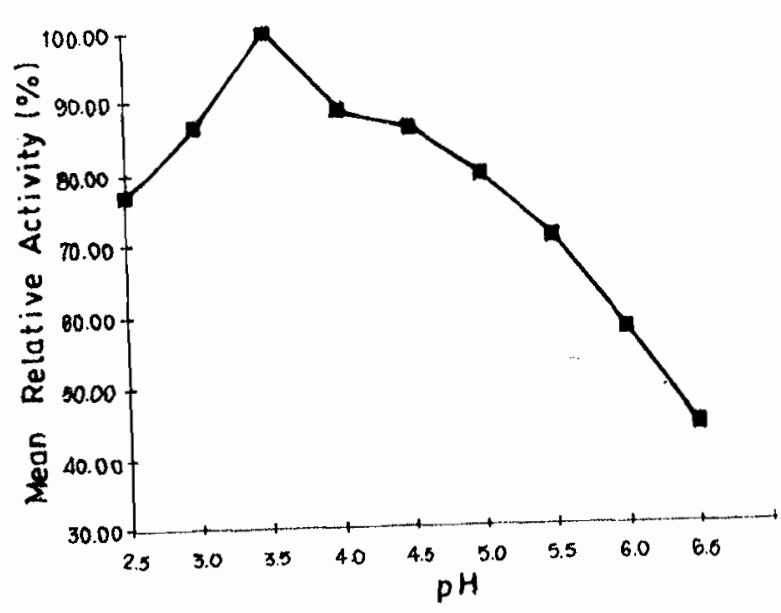

Figure 4: Effect of $\mathrm{pH}$ on acid protease stability

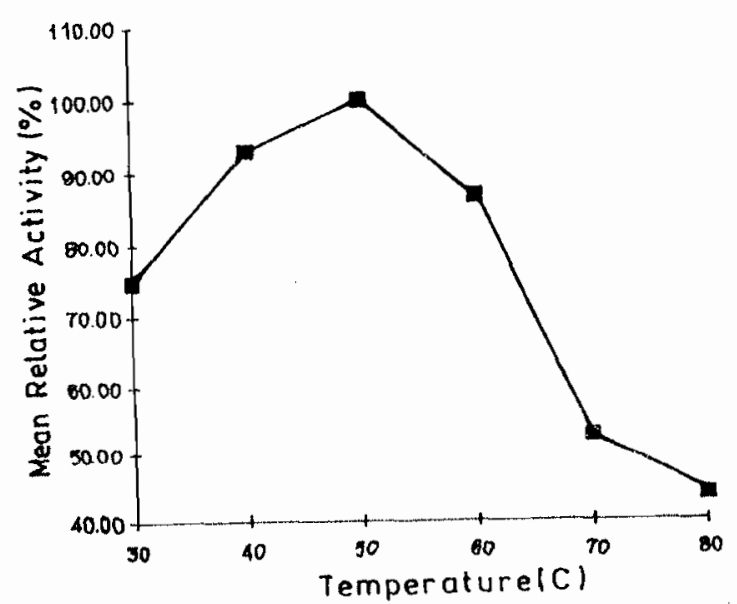

Figure 5: Effect of temperature on acid protease activity

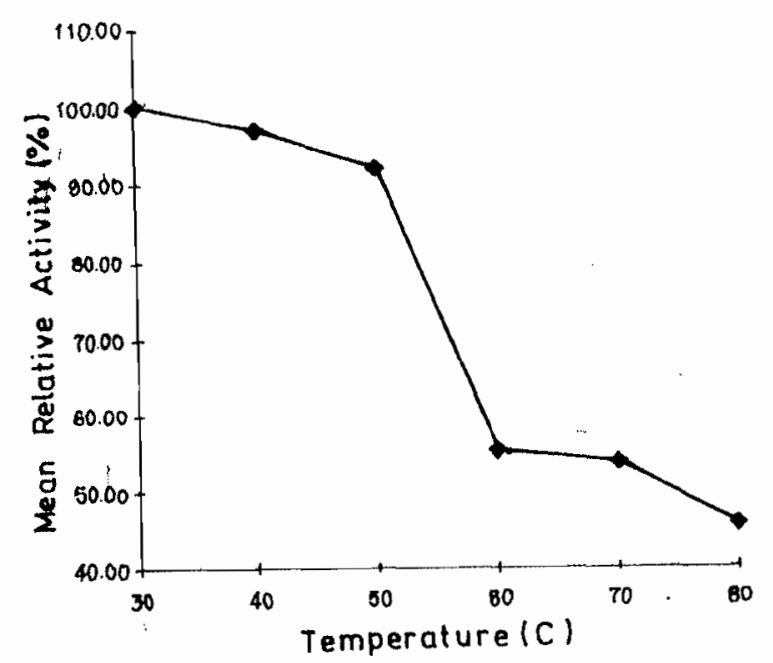

Figure 6: Effect of temperature on acid protease stability optimum/maximum activity was obtained (Fig. 5). After $50^{\circ} \mathrm{C}$ there was loss of activity. Exposure to temperature of $60^{\circ} \mathrm{C}$ resulted in a loss of about $13 \%$ of the maximum activity of acid protease. Activity of the enzyme however reduced drastically to about $50 \%$ of the maximum activity on exposure to temperature of $70^{\circ} \mathrm{C}$. Relative activity was expressed as a percentage of the activity at $50^{\circ} \mathrm{C}$ which was taken as $100 \%$.

\section{Effect of temperature on acid protease stability}

The acid protease was optimally stable at $30^{\circ} \mathrm{C}$ as shown in Fig. 6 . The relative residual activity was expressed as a percentage of the activity observed at $30^{\circ} \mathrm{C}$. The enzyme was said to be stable at any temperature at which activity was greater than $60 \%$. Acid protease from Aspergillus niger (NRRL 1785) was stable from $30^{\circ} \mathrm{C}$ up to $50^{\circ} \mathrm{C}$, but lost about $45 \%$ of its maximum activity at $60^{\circ} \mathrm{C}$ after 1 hour incubation at $\mathrm{pH} 4.0$.

\section{Effect of metal ions}

Table I shows the result of the influence of metal ions on acid protease activity. The enzyme was slightly activated in the presence of calcium and magnesium ions. Copper ion and lead ion had no effect on the activity of acid protease. Acid protease activity was inhibited in the presence of sodium and mercury ions.

\section{DISCUSSION}

The growth curve of Aspergillus niger (fig. 1) in the basal medium consisted of the lag phase, exponential phase, deceleration phase and the death phase. The lag phase (a period of no visible growth) was followed by the exponential phase that was recorded between the 12 and 60 hours of fermentation. The exponential phase witnessed the initial growth following spore germination when the total mycelia/ length/or biomass was increasing exponentially and growth was not affected by nutrient limitation or inhibitory effects of secondary metabolites. This agrees with the report of Neustroev and Fisrov (1990) on the growth kinetics of Aspergillus awamoris. The declining growth rate during the deceleration phase (60 - 84 hours) might be due to exhaustion of some nutrients in the media that became limiting or by the accumulation of waste products in the medium (Griffin, 1981). The death phase $\left(84^{\text {th }}-120^{\text {th }} \mathrm{hr}\right)$ might have resulted from the complete exhaustion of available nutrients most especially the carbon 
Table 1:Effect of metar ions on acid protease activity

\begin{tabular}{cc}
\hline Metal ions (50mM) & Relative activity (\%) \\
\hline Control $(0.00)$ & 100.00 \\
$\mathrm{Ca}^{2+}$ & 114.45 \\
$\mathrm{Na}^{+}$ & 67.57 \\
$\mathrm{Mg}^{2+}$ & 108.79 \\
$\mathrm{Hg}^{2+}$ & 77.99 \\
$\mathrm{Cu}^{2+}$ & 100.44 \\
$\mathrm{~Pb}^{2+}$ & 98.35 \\
\hline
\end{tabular}

source which provided the maintenance energy (Tan-Wilson et al, 1996)

The remarkable increase in the rate of acid protease synthesis which was highest between the $84^{\text {th }}$ and $96^{\text {th }}$ hour of fermentation (12 hours into the death phase) (fig.2) could have been due to the lytic processes occurring in the mycelium leading to the release of more acid protease into the fermentation medium, which already contained extracellular acid protease. During autolysis, lytic enzymes could have been activated while enzymes involved in synthesis were inhibited. Kritzmah et al (1978) reported a correlation between synthetic and lytic enzymes and hyphae formation in Sclerotium rolfsic. A similar report was obtained with proteinases of Eremothecium ashbyii (Koltsn et al, 1986).

Acid protease of Aspergillus niger NRRL 1195 was most active at $\mathrm{pH} 4.0$ (Fig. 3) Oyimum $\mathrm{pH}$ range for acid protease activity from Aspergillus saitoi (3.0 - 4.5), Aspergillus niger $(3.0-4.0)$, have been reported, (Gerhartz, 1990, Singh et al., 1994). Similar results were reported for acid protease from other fungi (Nizharadze et al. 1991; Chrzanowska et al. 1995; Ikasari and Mitchell, 1996; Wu and Hang, 1998). The enzyme was stable $(60 \%$ and above) over a pH range of $2.5-5.5$ (Fig.4). Similar results were observed for acid protease from Aspergillus saitoi and penicillium varioti (Cemartz, 1990), Aspergillus niger (Singh et. al., 1994) and Neosartorya fischerivar. spinosa (Wu and Hang, 1998). Reports have shown that most acid proteases are characterized by maximum activity and stability at $\mathrm{pH} 2.5-5.0$ (Boing, 1982).

The optimum temperature for acid protease activity from Aspengillus niger NRRL 1785 was $50^{\circ} \mathrm{C}$ (Fig. 5). Acid protease from Aspergillus saitoi and Rhizopus Oligosporus were reported to have optimum temperature of $30^{\circ} \mathrm{C}$ and $40^{\circ} \mathrm{C}$ respectively (Kalisz, 1988; Farley and Ikasari, 1992) while that of
Neosatorya Fischen var. spinosa was $50^{\circ} \mathrm{C}(\mathrm{Wu}$ and Hang, 1998). Acid protease of Aspergillus niger NRRL 1785 , was stable up to $50^{\circ} \mathrm{C}(60 \%$ relative activity) at $\mathrm{pH} 4.0$ for 1 hour (Fig. 6). Similar results were obtained for acid protease form Aspergillus saitoi and Neosartorya fischeri var spinosa (Tanaka et. al., 1977; Wu and Hang, 1998). Acid protease from Penicillin expansium was stable up to $45^{\circ} \mathrm{C}$ only (Abdel Fattah and Amr, 1987).

The activity of acid protease in this study was affected by metal ions. Though the enzyme was active in the absence of metal ions, calcium ion had an activating effect on the acid protease activity while mercury, and sodium ions had inhibitory effects. The result obtained with mercury ion contradicts reports by Boing (1982), Gerhartz (1990), Singh et al (1994) and Wu and Hang (1998) that acid protease is insensitive to heavy metals.

\section{CONCLUSION}

This study has shown the synthesis of acid protease by Aspergillus niger (NRRL 1785) to be dependent on phase of growth of the organism. The synthesis was maximal at the inception of the death phase of the organism. The acid protease synthesized had characteristics reminiscent of typical acid proteases in literature except influence on it by metal ions.

\section{REFERENCES}

Abdel - Fattah, A.F. and Amr, A.S., 1987. Production and Some Properties of a Partially Purified Rennin - Like Enzyme from Penicillium expansum, Agricultural Wastes 20: $35-41$.

Boing, J.T.P., 1982. Enzyme Production. In: Prescott and Dunn's Industrial Microbiology Ed. Reed, Connecticut: AVI G. 690pp.

Chrzanowska, J. Kolaczkowska, M., Dryjanski, M. Stachowiak, D. and Polanowski, A., 1995. Aspartic proteinase from Penicillium camemberti Purification, Properties and Substrate Specificity. Enzyme and Microbial Technology 17: 719-724.

Farley, T. and Ikasari, L., 1992. Regulation of the secretion of Rhizopus oligoporus extracellular carboxyl proteinase. Journal of General Microbiology. 138:25 $-39$

Gerhartz, W:, 1990. Enzyme in Industry: Production and Applications. 88pp. Weinheim: VCH.

Griffin, D.H., 1981. Molecular Architecture and Metabolism In: Fungal Physiology. John Wiley $\&$ Sons. Canada. pp $40-101$. 
Hagspiel K, Haab D, Kubicek, C.P., 1989. Protease activity and proteolytic modification of cellulases from a Trichoderma reesi QM 9414 selectant. Appl. Microbiol. Biotechnol. 32: 933-934.

Ikasari, L. and Mitchell, D.A. 1996: Leaching and Characterization of Rhizopus oligosporus acid protease from Solid - State Fermentation. Enzyme and Microbial Technology, 19: 171 - 175.

Kalisz, H.M. (1988): Microbial Proteases. In: Advances in Biochemical Engineering/Biotechnology. Ed. Fiechter, A. 36: 1 - 65. Berlin Heidelberg: Springer - Verlag.

Koltun, L.V., Tsvetkov, V.T. and Shavlouskii, G. M. 1986. Proteinases of the flavinogenic fungus erymothecium aslhbyii and some characteristics of their synthesis. Applied Biochem. And Microbiology 22:77-82

Kritzman, G., Chet, I., and Henis, G., 1978. Localization of $\beta(1,3)$ - Glucanase in the Mycelium of Sclerotium rolfsii. Bacteriol 134: 470-475.

Mchahon, H.E.M., Keth, K. T.and Forgarty, W.M., 1999. Thermostability of three X-amylases of Streptomyces sp. IMD2679 Journal of Industrial Microbiology and Biotechnology, 22: 96-99.

Neustroev K.N. and Firsov 1990. Acid proteinase and multiplicity of forms glucoamylase from Aspergillus awamori Biokhimiya 55: 776-785.
Nizharadze, D.N., Dolidze, T.I and Khuchua, T.O., 1991. Acid Protease from the Mesophilia Strain of $\mathrm{Mucor}$ - Plumbers Soobshcheniya Akademiya Nauk Gruzinskoi, 141: 181 -184.

Nout, M.J. and Rombouts, F. M., 1990. Recent Developments in Temple Research. Journal of Applied Bacteriology. 69: 609-633.

Sarath, G, de la Motte,R.S. and Wagner, F.W.(1989) Protease assay methods. In proteolytic Enzymes. A practical approach. Eds. Benyon, R.J. anad Bond J.J Pg 22-25. Oxford:IRL Press

Singh A., Ghosh, V.K. and Ghosh, P. 1994: Production of Themostable Acid Protease by Aspergillus niger. Letters in Applied Microbiology, 18, 177-180.

Tanaka, N., Takeuchi, M. and Ichishima, E. 1977: Purification of an Acid Proteinase from Aspergillus satoi and Determination of Peptide Bond Specificity. Biochemical et Biophisica Acta 485, 406 - 416.

Tan-Wilson, A.L. Liu, X, Chen, R, Oi, X., Wilson, K.A. 1996: An acidic amino acid-specific protease from germinating soybeans. Phytochemistry 42(2): 313319.

Wu, L.C. and Hang, Y. D., 1998 . Purification and Characterization of Acid Proteinase from Neosartorya fischeri var. spinosa IBT 4872. Letters in Applied Microbiology 27, 71 - 75. 